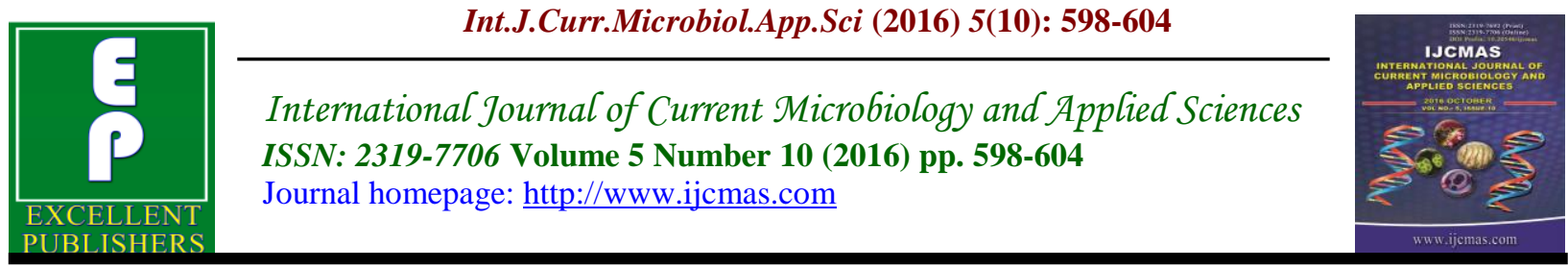

Original Research Article

http://dx.doi.org/10.20546/ijcmas.2016.510.067

\title{
Assessment of Widal Tube Agglutination Test and its Baseline Titres in Amritsar an Endemic Area
}

\author{
Ashish Khanna $^{{ }^{*}}$ and Menka Khanna ${ }^{2}$ \\ ${ }^{1}$ Department of Microbiology, Sri Guru Ram Das Institute of Medical Sciences and \\ Research, Punjab, India \\ ${ }^{2}$ Department of Pathology, Sri Guru Ram Das Institute of Medical Sciences and \\ Research, Punjab, India \\ *Corresponding author
}

\begin{tabular}{|c|c|}
\hline & \multirow{7}{*}{ 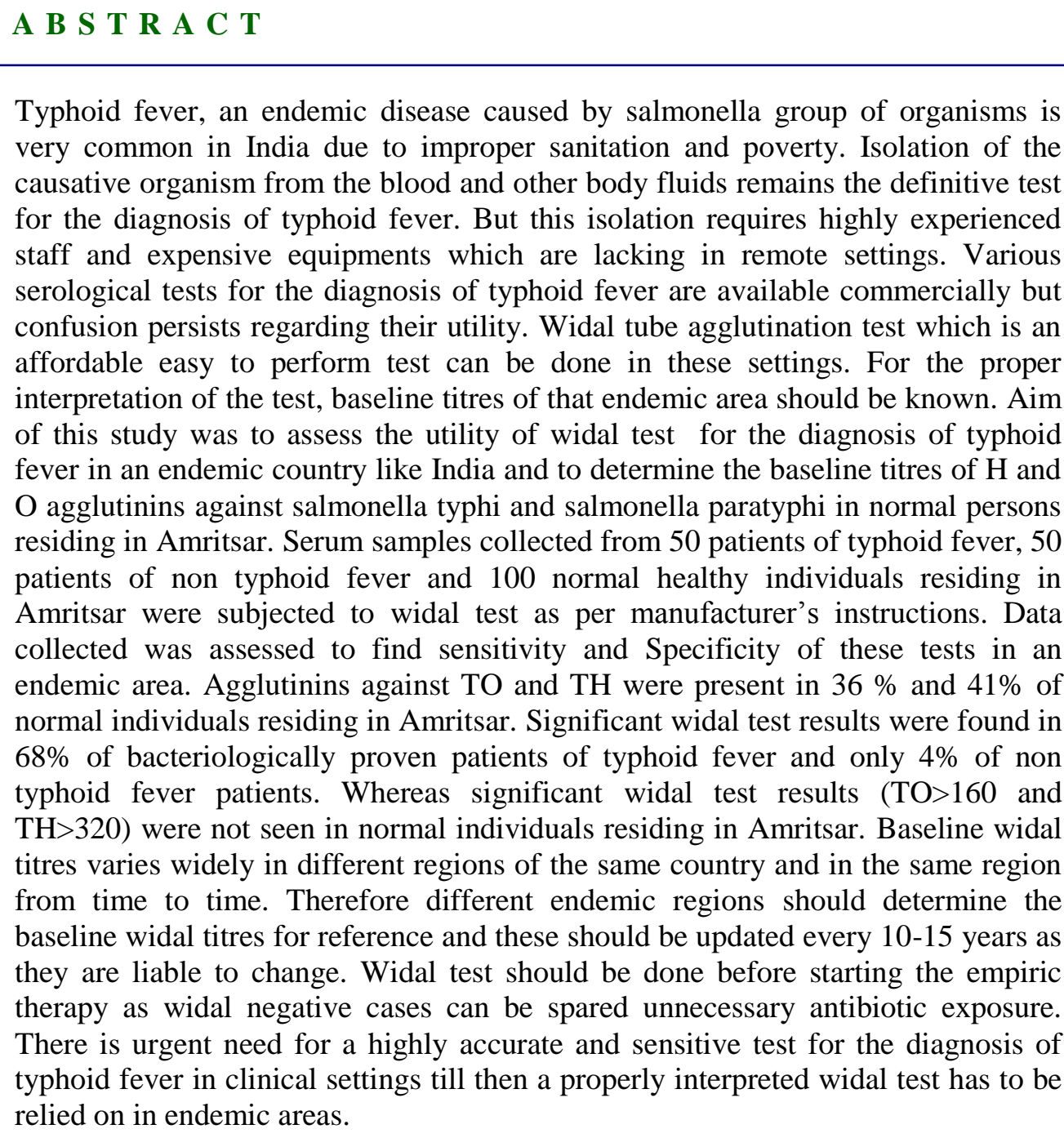 } \\
\hline & \\
\hline Keywords & \\
\hline $\begin{array}{l}\text { Salmonella, } \\
\text { Widal test, } \\
\text { Typhoid fever. } \\
\text { Agglutination. }\end{array}$ & \\
\hline Article Info & \\
\hline $\begin{array}{l}\text { Accepted: } \\
\text { 20 September } 2016 \\
\text { Available Online: } \\
10 \text { October } 2016\end{array}$ & \\
\hline & \\
\hline
\end{tabular}




\section{Introduction}

Infectious diseases remain a common cause of death and debility and are responsible for worsening the living condition of many millions of people around the world. A number of social and economic factors like poverty, lack of access to healthcare, antibiotic resistance, human migration pattern and changing environmental and developmental activities all contribute to the expanding impact of infectious diseases in a developing country like India. This is particularly so in case of infectious disease like typhoid fever, which is still a fairly common disease in tropical and subtropical countries (Lawrence et al., 1998).

Typhoid fever is a systemic infectious disease characterized by an acute illness, the first typical manifestations of which are fever, headache abdominal pain, relative bradycardia, splenomegaly and leucopenia. Salmonella enterica subsp enteric serotype typhi is the etiological agent of typhoid fever (Pearson et al., 2000).

The definitive diagnosis of the disease require isolation of Salmonella typhi and Salmonella paratyphi from blood, faeces, urine and other body fluids (Gilman et al., 1975). This is often not possible as facilities for isolation, culture, biochemical and serological identification are not available in many smaller hospitals. Moreover many time patients engage in antibiotic self medication, which limits the number of positive culture reported. The relative higher cost of performing the culture tests combined with their low sensitivity as well as the delay in obtaining results, have made the widal agglutination test the single most used method for the diagnosis of typhoid fever in India. Since its description in 1896 (Bulletin Social Medicine) (Widal, 1896), the widal test has been extensively used for the diagnosis of typhoid fever. The test is based on demonstrating the presence of antibodies in the serum of an infected patient, against the $\mathrm{H}$ (flagellar) and $\mathrm{O}$ (somatic) antigens of Salmonella typhi and Salmonella paratyphi.

Although a number of reports from some developing countries have suggested that a single widal test is sufficient to make the diagnosis of typhoid fever (Mohammed et al., 1992), others have disputed the usefulness of a single test result (Olopenia et al., 2000; Levine et al., 1978). Baseline widal titres varies widely in different regions of the same country and in the same region from time to time.

Therefore different endemic regions should determine the baseline widal titres for reference and these should be updated every $10-15$ years as they are liable to change. In the setting of endemic areas, interpretation of the widal test hinges on the knowledge of the seroprevalence of positive antibody titres among healthy members of the population. Taking all this into consideration the present study was carried out to find the appropriate baseline titre for diagnosing typhoid fever in Amritsar.

\section{Materials and Methods}

Blood samples were collected from three group of individuals observing strict aseptic precautions after taking the informed consent.

Group - I - 100 normal healthy individuals residing in Amritsar.(Punjab)

Group II -comprised of 50 patients attending different medical units of Sri Guru Ram Das Institute of Medical Sciences and Research, Amritsar with a definite diagnosis of typhoid fever as indicated by isolation of Salmonella typhi and Salmonella paratyphi from blood.

Group - III comprised of 50 patients with non enteric fever who had not been 
previously immunized with $\mathrm{TAB}$ vaccine. These included patients with urinary tract infection, respiratory tract infection, other infections like wound infection, burns and malaria. The diagnosis was made on the basis of laboratory tests such as demonstration of malarial parasite in peripheral blood film, sputum smear, positive urine culture, pus and blood culture.

Blood samples from patients in all the three groups were collected under asceptic conditions. $5 \mathrm{ml}$ of the blood collected was put in the bile broth for blood culture and 2 $\mathrm{ml}$ was put in a vial for separation of serum to be used for widal test.

A co-incidental salmonella infection was excluded by repeated blood cultures in group I and III also.

Isolation of Salmonella typhi from blood was carried out using standard procedures. Blood specimen were subcultured on blood and MacConkey agar following overnight incubation at $37^{\circ} \mathrm{C}$ in Bile broth. (In case there was no growth then blood culture bottles were reincubated further for seven days. These bottles were observed for signs of growth daily and were subcultured before being discarded) Further identification was based on biochemical reactions and agglutination with specific antisera (C.R.I. Kasauli).

The serum was separated with sterile precautions from $2 \mathrm{ml}$ of the clotted blood taken from the patient earlier along with blood collected for culture. Widal test was carried out by tube dilution technique with the antigens obtained from C.R.I. Kasauli.

Serial dilution of sera (in normal saline) were performed starting at a dilution of 1/20. $0.2 \mathrm{ml}$ of the respective antigen obtained from C.R.I. Kasauli was put in the tubes except the control tubes. The racks with tubes were incubated in a water bath. For $\mathrm{H}$ type agglutination tubes were incubated for 2 hours at $55^{\circ} \mathrm{C}$ and then left at room temperature for half an hour before reading the result. For $\mathrm{O}$ type agglutination, incubation was done at $37^{\circ} \mathrm{C}$ for four hours, followed by overnight refrigeration.

\section{Results and Discussion}

The titre of $\mathrm{H}$ and $\mathrm{O}$ agglutinins against Salmonella typhi among all the three group of individuals are given in table I. Based on the titre of agglutinins in normal individuals, a titre of $\geq 1: 160$ for $\mathrm{O}$ and $\geq 1: 320$ for $\mathrm{H}$ were taken as significant and indicative of typhoid fever. Using the above criteria the significant widal test results in typhoid and non typhoid fever group were calculated as shown in table II. Seventy six percent patients in the typhoid fever group showed significant widal test result and among these significant $\mathrm{O}$ titre only were seen in 10 percent and significant $\mathrm{H}$ titre only were seen in 16 percent. (table III). In the present study, of the 17 cases in the typhoid fever group who had taken prior antibiotics significant widal test results were obtained in 10 and of the 33 cases who had not taken prior antibiotics 28 showed significant widal test result. ( $p<.05)$.The relationship of widal test result in typhoid fever group with duration of fever is also shown in table III.

The serum of proportion of persons in any country contain antibodies capable of reacting to a variable titre in the widal test. In the absence of previous inoculation with typhoid vaccine, the frequency of agglutinins in a population reflects its experience of samonella either in the form of enteric fever or latent infection and therefore varies widely from country to country (Schroeder, 1968).

In the present study, agglutinins against $\mathrm{O}$ antigen of Salmonella typhi were obtained in 36 percent of individuals and against $\mathrm{H}$ 
antigen of Salmonella typhi in 41 percent of normal healthy individuals. Agglutinin against $\mathrm{O}$ antigen were present in the present study in titres of 1:80 in 4 percent of healthy individuals and $\mathrm{H}$ agglutinins against Salmonella typhi were present in titres of 1:160 in 2 percent of healthy individuals residing in Amritsar (Table I). High titres in normal individuals obtained in the present study were in accordance to the high titres obtained in other endemic areas (Wicks, 1971). As interpretation of widal test must be made against this baseline information, agglutination titres considered as significant for evaluating the result of widal test in the present study were $>$ or $=1: 160$ for $\mathrm{O}$ antigen and >or $=1: 320$ for $\mathrm{H}$ antigen of Salmonella typhi. Similar diagnostic criteria have been used by other workers in their studies.

The result of the widal test performed on fifty patients of bacteriologically proven typhoid fever showed that agglutinins against $\mathrm{O}$ antigen of Salmonella typhi were present in 92 percent cases and against $\mathrm{H}$ antigen of Salmonella typhi in 98 percent of cases.(Table II) Significant widal test results ( $\mathrm{O}$ titres $>$ or $=1: 160$ and $\mathrm{H}$ titres $>$ or $=1$ : 320 ) were obtained in 76 percent of cases of typhoid fever.

The highest titre of $\mathrm{O}$ agglutinins was > 1:1280 in 2 percent cases and $\mathrm{H}$ agglutinin was > 1:1280 in 4 percent cases(Table II).Similar results were obtained by other workers however higher percentage of significant widal test results were seen by some authors (Senewiratne et al., 1977; Sen et al., 1969).

While majority of patients (98 percent) of non typhoid fever in our study showed non significant widal test result, a diagnostic widal test result was obtained in only 2 percent of cases of non typhoid fever(Table II). Pang and Puthucheary found significant widal test result in 3 percent cases of non typhoid fever whereas Senewirante and Senewirante found significant widal test result in 1 percent cases of non typhoid fever.

In the present study the blood samples were collected in the first week of illness in 15 patients in typhoid fever group and among them 8 (53.3percent) showed significant widal test result This could be attributed to the hyper immune state in the population in endemic areas who are frequently exposed to typhoid bacilli. Early appearance of $\mathrm{H}$ and $O$ agglutinins is seen in these immunologically sensitized persons living in these endemic areas as reported in other studies. It has been reported in literature that previous inoculation with $\mathrm{TAB}$ vaccine could make the interpretation of widal test result difficult as $\mathrm{H}$ agglutinins may persist for years after $\mathrm{TAB}$ inoculation (Parker, 1990). This was not a problem in our study since almost all the patients of typhoid fever, non typhoid fever and normal healthy individuals gave no history of TAB inoculation.

Comparison of widal test result in patients of typhoid fever who had taken prior antibiotics(17 cases) with those without prior antibiotic treatment(33 cases) was found to be statistically significant $(\mathrm{p}<.05)$ Among the 12 Patients of typhoid fever showing non significant widal test result 7 had taken full course of antibiotics (chloremphenicol, ampicillin and cotrimoxazole ).

The widespread practice of empirical use of antibiotics (Chloramphenicol, Ampicillin and Cotrimoxazole ) could delay or even inhibit the formation of agglutinins against various antigens of Salmonella typhi. Early treatment with these drugs had a profound effect on the antibody response. 
Table.1 Comparative titre of Salmonella typhi agglutinins (TO and TH) in 50 patients of typhoid fever, 50 patients of non typhoid fever and 100 normal healthy individuals.

\begin{tabular}{|c|c|c|c|c|c|c|c|c|c|}
\hline Category & Antigen & \multicolumn{8}{|c|}{ Reciprocal of antibody titre } \\
\cline { 3 - 11 } & & $<20$ & 20 & 40 & 80 & 160 & 320 & 640 & 1280 \\
\hline \multirow{2}{*}{ Typhoid group } & TO & 4 & 4 & 4 & 8 & 15 & 10 & 4 & 1 \\
\cline { 2 - 11 } & TH & 1 & 1 & 1 & 5 & 9 & 19 & 12 & 2 \\
\hline \multirow{2}{*}{$\begin{array}{c}\text { Non Typhoid } \\
\text { group }\end{array}$} & TO & 33 & 8 & 5 & 3 & 1 & - & - & - \\
\cline { 2 - 11 } & TH & 29 & 8 & 6 & 4 & 2 & - & 1 & - \\
\hline $\begin{array}{c}\text { Normal } \\
\text { healthy group }\end{array}$ & TO & 64 & 18 & 14 & 4 & - & - & - & - \\
\cline { 2 - 10 } & TH & 59 & 16 & 13 & 10 & 2 & - & - & - \\
\hline
\end{tabular}

Table. 2 Showing comparison of widal test results in 50 patients of typhoid fever, 50 patient of non typhoid fever and 100 normal healthy individuals .

\begin{tabular}{|c|c|c|c|c|c|}
\hline \multirow[t]{2}{*}{$\begin{array}{l}\mathrm{Sr} \\
\mathrm{No}\end{array}$} & \multirow[t]{2}{*}{ Group } & \multirow[t]{2}{*}{$\begin{array}{l}\text { Total no } \\
\text { of cases }\end{array}$} & \multicolumn{2}{|c|}{$\begin{array}{l}\text { Significant result for } \mathrm{O} \text { and } \mathrm{H} \\
\text { agglutinins }\end{array}$} & \multirow{2}{*}{$\begin{array}{l}\text { Significant } \\
\text { widal test } \\
\text { results }\end{array}$} \\
\hline & & & $\mathrm{O}>$ or $=160$ & $\mathrm{H}>$ or $=320$ & \\
\hline I & Typhoid & 50 & $30(60 \%)$ & $33(66 \%)$ & $38(76 \%)$ \\
\hline II & $\begin{array}{l}\text { Non typhoid } \\
\text { fever }\end{array}$ & 50 & $1(2 \%)$ & $1(2 \%)$ & $1(2 \%)$ \\
\hline III & $\begin{array}{c}\text { Normal } \\
\text { healthy } \\
\text { individual }\end{array}$ & 100 & NIL & NIL & NIL \\
\hline
\end{tabular}

Table.3 Showing relation between titre of $\mathrm{TO}$ and $\mathrm{TH}$ agglutinins and duration of fever in typhoid fever group.

\begin{tabular}{|c|c|c|c|c|}
\hline \multirow{2}{*}{ Group } & \multicolumn{3}{|c|}{ Duration of fever(Days) } & \multirow{2}{*}{ Total } \\
\cline { 2 - 4 } & $0-7$ & $8-14$ & $>15$ & 5 \\
\hline $\begin{array}{c}\text { No. with significant O } \\
\text { titre only. }\end{array}$ & 1 & 3 & 1 & 8 \\
\hline $\begin{array}{c}\text { No. with significant H } \\
\text { titre only }\end{array}$ & 2 & 4 & 2 & 25 \\
\hline $\begin{array}{c}\text { No with significant O \& } \\
\text { H titre only }\end{array}$ & 5 & 12 & 8 & 12 \\
\hline $\begin{array}{c}\text { No with Nonsignificant } \\
\text { O and H titres }\end{array}$ & 7 & 2 & 3 & 50 \\
\hline Total & 15 & 21 & 14 & \\
\hline
\end{tabular}


If agglutinins have not appeared when treatment has begun, they are unlikely to do so subsequently. If antibodies are already present, then there may be no further rise in titres with the progression of disease (ElRooby et al., 1956).

In our study significant titre of $\mathrm{O}$ and $\mathrm{H}$ agglutinins were found in $60 \%$ and $66 \%$ of confirmed patients of typhoid fever. As the difference was statistically insignificant (p>.05) we found that both $\mathrm{O}$ and $\mathrm{H}$ agglutinins were equally important for the diagnosis of typhoid fever. This was in contrast to widely held belief among clinicians that a raised $\mathrm{O}$ agglutinin titre was of greater diagnostic value than the raised titre of $\mathrm{H}$ agglutinin. But Brodie (1991) in his study of the 1964 Aberdeen outbreak involving 403 cases reported that $\mathrm{H}$ agglutinins did not develop in 15 percent of patients tested and $\mathrm{O}$ antibodies did not develop in as many as 41 percent.

With regards to the possibility of false positive reactions, the present study has shown that the large majority of sera from proven cases of other febrile illnesses common in the region eg urinary tract infection, malaria, tuberculosis, wound infection and septicemia did not give a significant widal test results. Only one patient( 2 percent) showing false positive reaction in non typhoid fever group in our study was suffering from falciparum malaria. Similar false positive widal reactions in malaria have been seen in other studies also (Samal et al., 1991; Sharma et al., 1993). However these findings do not discount the possibility of false positive reaction seen in infections with other salmonellae, immunological disorders and chronic active hepatitis as seen in various studies (Reynolds et al., 1970).

To conclude, the widal test is an easy inexpensive test that can be of diagnostic value in unvaccinated individuals in endemic areas in situations where blood culture cannot be obtained as in a developing country like India. Both the agglutinins, Somatic and Flagellar, are equally important for that purpose. But the result of the widal test must be interpreted cautiously with the foreknowledge of the tests shortcomings. Increasing false positive tests with some serological tests have lead to emergence of resistant strains in India. Widal test should be done before starting the empiric therapy as widal negative cases can be spared unnecessary antibiotic exposure. Still there is a scope for higher sensitive and accurate test for the early diagnosis of typhoid fever till then a properly interpreted widal test has to be relied on in endemic areas.

\section{References}

Brodie, J. 1977. Antibodies in the Aberdeen typhoid outbreak of 1964.I. The widal reaction. J. Hyg. Camb., 79: 161-9.

Cruickshank, R., Duguid, J.P., Marmion, B.P., Swain, R.H.A. 1970. In: Medical Microbiology, $12^{\text {th }}$ Edn, Churchill Livingstone, London, 908.

El-Rooby, A., Gohar, M.A. 1956. Effect of chloramphenicol on agglutinin titre in enteric fevers. J. Trop. Med. Hyg., 59: 47-51.

Gilman, R.H., Terminalm, Levine, M.M., Hernandez-Mandoza, P., Hornick, R. 1975. Comparison of relative efficacy of blood, stool, urine, bone marrow and rose spot cultures for recovery of Salmonella typhi in typhoid fever. Lancet, 1: 1211-3.

Lawrence, C.M., Dennis, L.K. 1998. Introduction to infectious diseases: Host parasite interaction. In: Fauci AS, Braunwald $\mathrm{E}$, Isselbacher KJ, Wilson JD, Martin JB, Kasper DL et al(Eds) : Harrisons Principles of Internal 
Medicine, $14^{\text {th }}$ Edn, New York, McGraw Hill, 749-54.

Levine, M.M., Gardos, O., Gilman, R.H., Woodward, W.E., Solis-Plaza, R., Waldman, W. 1978. Diagnostic value of Widal test in areas endemic for typhoid fever. Am. J. Trop. Med. Hyg., 27: 795-800.

Mohammed, I., Chkwen, J.O., Gasshau, W. 1992. Determination by Widal agglutination of baseline titre for the diagnosis of typhoid fever in two Nigerian states. Scand J. Immunol., 11: 153-6.

Olopenia, L.A., King, A.L. 2000. Widal agglutination test -1000 years later still plagued by controversy. Post Grad. J., 76(892): 80-4.

Pang, T., Puthucheary, S. 1983. Significance of widal test in diagnosis of typhoid fever in endemic areas. J. Clin. Pathol., 36: 471-5.

Parker, M.T. 1990. Enteric infections: typhoid and paratyphoid. In Parker MT and Collier LH (ed), Topley and Wilson's principles of bacteriology, virology and immunology, vol III , $8^{\text {th }}$ ed Arnold publisher, London, 424-46.

Pearson, R.D., Guerrant, R.L. 2000. Enteric fever and other causes of abdominal symptoms with fever. In: Mandell GL, Bennet JE, dolin R (editors),Principles and practice of infectious diseases, $5^{\text {th }}$ ed Churchill Livingstone, New York, 1136-50.

Reynolds, D.W., Carpenter, R.L., Simon, W.H. 1970. Diagnostic specificity of widal's reaction for typhoid fever. JAMA, 214(12): 2192-3.

Samal, K.K., Sahu, C.S. 1991. Malaria and widal reaction. J. Assoc. Phy. India, 39: 745-7.

Schroeder, A.S. 1968. Interpertation of serologic tests for typhoid fever. JAMA, 206: 839-40.

Sen, R., Saxena, S. 1969. A critical assessment of the conventional Widal test in the diagnosis of typhoid and paratyphoid fevers. Indian Med. Res., 57: 1813-9.

Senewiratne, B., Senewiratne, K. 1977. Reassesment of the Widal test in the diagnosis of typhoid. Gastroentrol., 73: 233-6.

Sharma, J.R., Parmar, I.B., Sharma, S.J., Keshavan, A. 1993. False positive widal reaction in malaria. Ind. Paediatr., 30: 1343-7.

Wicks, A.C.B., Holmes, G.S., Davidson, L. 1971. Endemic typhoid fever -a diagnostic pitfall. Q. J. Med., 40: 34154.

Widal, F.M. 1896. Sero diagnostic del la fievre typhoide. Bull. Soc. Med. Hop. Paris, 13: 561-6.

\section{How to cite this article:}

Ashish Khanna and Menka Khanna. 2016. Assessment of Widal Tube Agglutination Test and its Baseline Titres in Amritsar an Endemic Area. Int.J.Curr.Microbiol.App.Sci. 5(10): 598-604. doi: http://dx.doi.org/10.20546/ijcmas.2016.510.067 